\title{
The psychiatry of opera
}

The first in an occasional series.

\author{
MARK Jones, Registrar, Department of Psychological Medicine, St Bartholomew's \\ Hospital, London EC3
}

\section{A personal view}

That art is an expression of man's attempts to understand himself and his environment is as important as the purely aesthetic qualities of the piece, whatever it may be. Opera, together with the other performing arts, literature and painting, cannot simply be seen as pure entertainment. It is also a reflection of the society in which the composer and librettist lived, and the issues and values contemporary to those people. Opera with its fusion of words, music and theatre is able to delineate those issues involved and present them with an emotional intensity possibly unequalled elsewhere in art. Musical imagery is used to portray and develop the characters in opera by inflecting the librettist's words and embedding them in a sound world. This is how we can gain access to those characters' thoughts and emotions. As psychodramas the works of the late 19th and the 20th centuries reach the greatest level of complexity.

\section{The librettist and opera}

In working at the characters who populate operas, we are viewing a reflection of society and the way in which people react and relate to each other; however this may not always be the focus of the drama. Operas are in no way homogeneous in construction and content. The themes they tackle are as varied as the whole of literature; also the construction of the score and libretto will reflect the composer's style and period of writing. Certain themes were popular at particular times, e.g. the operas of Monteverdi and Handel deal with Greek legends, gods and heroes, and they reflected public taste.

\section{The producer's opera}

Broadly speaking, opera libretti are rarely completely new thoughts on a subject and are mostly extracted from existing works, then shaped by the librettist into a form that can be integrated with music. Any analysis of the thematic material that underpins an opera should at least briefly look at the source of the libretto. Indeed, the style of opera in the 1980 s became increasingly 'deconstructionalist', i.e. looking at a work from the source material upwards and making use of historical and psychological elements. This anatomical method of production needs a producer who really understands the opera. He must have a deep sense of what the work is about, be able to analyse, understand and convey to the audience what is essentially the subtext. This much freer interpretation allows the audience to connect with the stage in a way not previously explored by producers. The score and text remain intact, vocal and musical values are still cherished, but the new generation of opera singers is required to act and get involved in the drama with more understanding and conviction than ever before.

The 'producer's opera' is a great challenge to the emotional and intellectual capabilities of audiences, and its demands are simply too great for many traditionalists. In the search to understand our own psychology opera is rich in insight, and with the advent of the new theatricality the time is right to look at the psychology and psychopathology within these works. In considering such themes it is the presentation by the composer and librettist of the characters in musical, verbal and dramatic terms, as well as recent interpretations that will form the basis of the following discussions. It will also help us to see these works in context if we look also at the socioeconomic, political and mental health attitudes prevalent at the time.

\section{Suicide and opera}

In subsequent articles $I$ intend to work through a number of operas presenting them chronologically, starting with some early pieces, and ending up with 20 th century operas. Each 'vignette' will try to give some psychiatric insight into the characters under scrutiny, and place them in a framework of social and musical history. Some readers may remember Graeme Feggetter's article 'Suicide in Opera' (Feggetter, 1980), which undertakes an exploration of "... popular attitudes to suicide ... by studying the way in which suicide has been portrayed in a $p^{n+r}:$ rular art form ...". It might be as well to review 


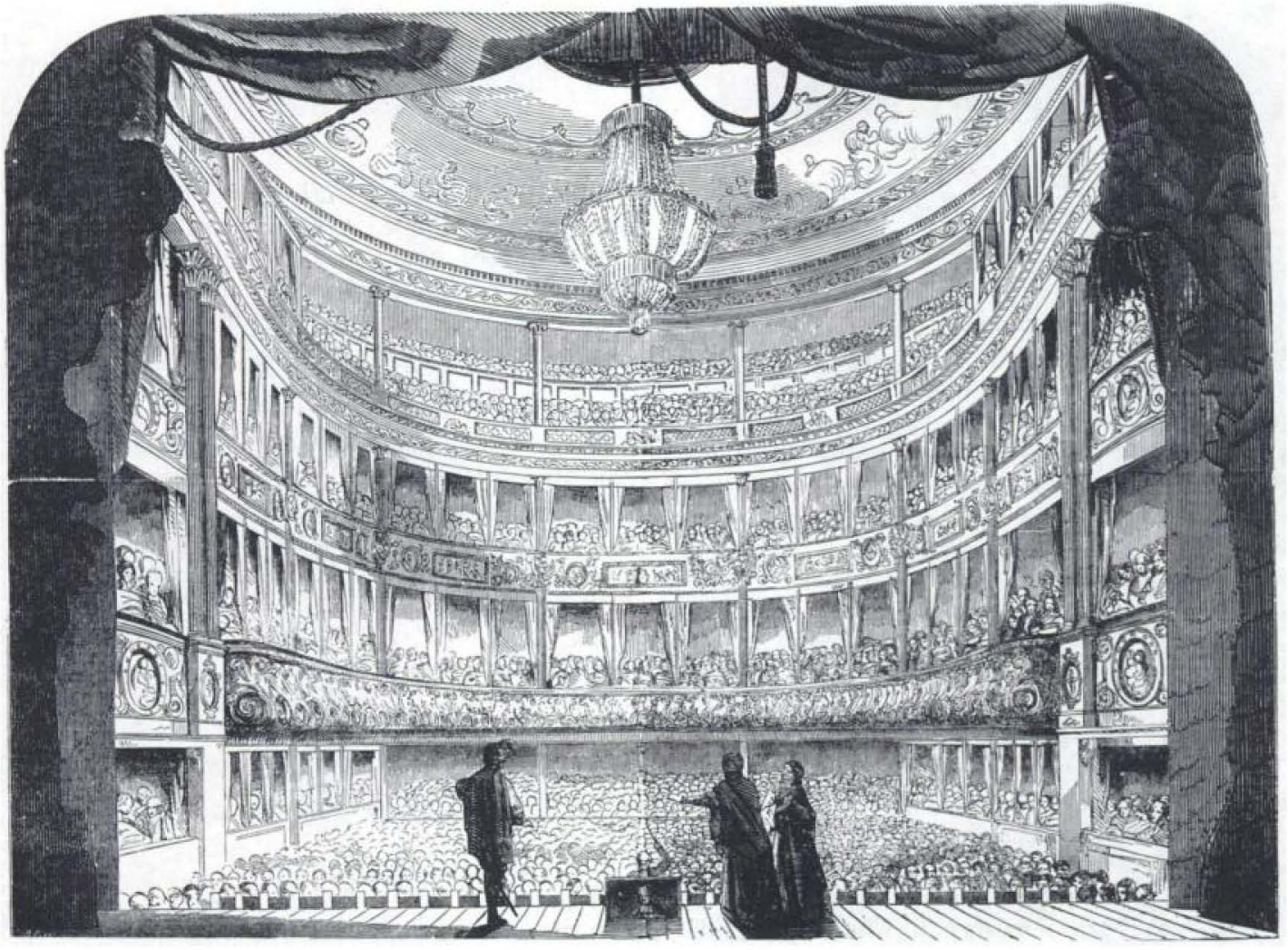

The Royal Italian Opera, Lyceum (copyright The Illustrated London News Picture Library).

his thoughts on this matter since they will crop up again throughout subsequent analyses.

This one-off piece stemmed from a talk he gave to some Oxford colleagues, the theme for which emerged naturally as he selected some musical examples. The core issue is one of "changing attitude(s) towards successful suicide and suicidal behaviour", seen from an operatic viewpoint. Despite the thousands of publications on suicide written over the years, historical surveys illustrating the popular view, says Feggetter, are few. That suicide began to vie with TB as a cause of operatic death, although overstated, is a valid observation when we look at 19th century operas. Given the penalties incurred by suicide in Stuart England (MacDonald, 1977), some shift in attitude must have occurred between the strict religious views prevalent in the 17th century and its presentation in graphic terms in a late 19th or 20th century opera acceptable to a thinking public. Feggetter treats us to a saunter through the repertoire outlining plots as we go. Selected operas illustrate the different 'types' of suicide in terms of the characters motivations and the way that some scenarios conform to Barraclough's observations or, perhaps, fits one of Durkheim's classifications. As the author rightly points out, the difficulty of using fictional characters is that no objective, independent evidence exists, only the 'internal' evidence of the operas. That he has been very selective in the works discussed is also true, but who can blame him given the size of the repertoire and his attempt at a clinical analysis in the absence of hard material?

Over the last decade opera has picked itself up, dusted itself down and discarded its museum-art image. Today, producers and public alike are in search of challenging, exciting theatre. I hope that in this occasional series I can communicate why this complex and thrilling art form can divulge so much about human nature. This, it seems to me, is why it can be realistically thought of in psychiatric terms and, whether opera-lovers or not, you can be made to look more appreciatively at its creators' minds.

\section{References}

FegGetter, G. (1980) Suicide in opera. British Journal of Psychiatry, 136, 552-557.

MacDonald, M. (1977) The inner side of wisdom: suicide in early modern England. Psychological Medicine, 7, $565-582$. 